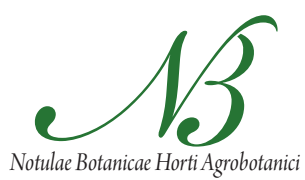

Cluj-Napoca

\title{
Reactive Oxygen Species, Lipid Peroxidation and Antioxidative Defense Mechanism
}

\author{
Hossam S. EL-BELTAGI ${ }^{*}$, Heba I.MOHAMED² \\ ${ }^{1}$ Cairo University, Faculty of Agriculture, Biochemistry Department, P. Box 12613, Gamma \\ St, Giza, Cairo,Egypt; lbltg@yahoo.com ("correspondingauthor) \\ ${ }^{2}$ Ain Shams University, Faculty of Education, Biological and Geological Sciences Department, El Makres St. Roxy, Cairo 1575, Egypt (ARE)
}

\begin{abstract}
Lipid peroxidation can be defined as the oxidative deterioration of lipids containing any number of carbon-carbon double bonds. Lipid peroxidation is a well-established mechanism of cellular injury in both plants and animals, and is used as an indicator of oxidative stress in cells and tissues. Lipid peroxides are unstable and decompose to form a complex series of compounds including reactive carbonyl compounds. The oxidation of linoleates and cholesterol is discussed in some detail. Analytical methods for studying lipid peroxidation were mentioned. Various kinds of antioxidants with different functions inhibit lipid peroxidation and the deleterious effects caused by the lipid peroxidation products.
\end{abstract}

Keywords: antioxidants, cholesterol, fatty acids, lipid peroxidation

\section{Introduction}

Lipids is a heterogeneous group of compounds having several important functions in the body such as being an efficient source of energy, constituents in cell membranes and nerve tissues, thermal and electrical insulators and acting as local hormones etc (Murray et al., 2000). They are also important dietary constituents not only because of their high-energy value but also because of the fat-soluble vitamins and essential fatty acids that are contained in the fat of natural foods. Energy is produced from lipids in the body when lipids are $\beta$-oxidized and oxygen is reduced to water in the respiratory chain by mitochondria in different tissues (Murray et al., 2000). When lipids are oxidized without release of energy, unsaturated lipids go rancid due to oxidative deterioration when they react directly with oxygen molecule (de Zwart et al., 1999; Gutteridge, 1995; Gutteridge and Halliwell, 1990, 1994; Halliwell and Gutteridge, 1990, 1999; Halliwell and Chirico, 1993; Moore and Roberts, 1998). This process is called lipid peroxidation (LPO) and the insertion of an oxygen molecule is catalyzed by free radicals (non-enzymatic lipid peroxidation) or enzymes (enzymatic lipid peroxidation) (Gutteridge, 1995; Halliwell and Gutteridge, 1990). It has been shown that LPO induces disturbance of fine structures, alteration of integrity, fluidity, and permeability, and functional loss of biomembranes, modifies low density lipoprotein (LDL) to proatherogenic and proinflammatory forms, and generates potentially toxic products (Greenberg et al., 2008). Further, LPO products have been shown to be mutagenic and carcinogenic (West and Marnett, 2006). The reactive carbonyl compounds, the secondary products of LPO, modify biologically essential molecules such as proteins and DNA bases (Esterbauer et al., 1991; Poli et al., 2008a; Uchida, 2003). Thus LPO in vivo has been implicated as the underlying mechanisms in numerous disorders and diseases such as cardiovascular diseases, cancer, neurological disorders, and aging. Consistent with this notion, numerous studies show increased levels of LPO products in the biological fluids and tissues from the patients compared with healthy subjects. At the same time, it became evident recently that LPO products as well as ROS/RNS exert various biological functions in vivo such as regulators of gene expression, signaling messengers, activators of receptors and nuclear transcription factors, and inducers of adaptive responses (Ceaser et al., 2004; Forman et al., 2008; Noguchi, 2008; Poli et al., 2008b). Recent studies provided evidence that many LPO products exert opposite dual effects depending on the conditions, such as cytotoxic and cytoprotective effects, pro- and antiatherogenic effects, pro- and antiapoptotic effects, and pro- and anti-inflammatory effects (Parthasarathy et al., 2000; Zmijewski et al., 2005).

\section{Free radicals and other reactive species}

A free radical may in simple terms be defined as an atom or molecule that contains one or more unpaired electrons and is capable of independent existence (Halliwell and Chirico, 1993; Halliwell and Gutteridge, 1990; Slater, 1984). An unpaired electron is an electron that occupies an orbital alone (indicated in the text by $\bullet$ ), but 
electrons usually associate in pairs in orbitals of atoms and molecules. Free radicals are generally more reactive than non-radicals due to their unpaired electron, but different types of free radicals vary widely in their reactivity (Halliwell, 1994; Halliwell et al., 1995; Rice-Evans and Burdon, 1993). The oxygen molecule $\left(\mathrm{O}_{2}\right)$ qualifies as a free radical because it contains two unpaired electrons, but is not particularly reactive due to a special electron arrangement that makes the reactions with oxygen spin restricted (Halliwell and Gutteridge, 1990). However, when oxygen is partly reduced, several different reactive oxygen species (ROS), both radicals and non-radicals, may be produced (Halliwell and Chirico, 1993). ROS are the byproducts of many degenerative reactions in crop plants, which will affect the regular metabolism by damaging the cellular components (Foyer and Noctor, 2002). Extensive study on oxidative stress has demonstrated that exposure of plants to adverse environmental conditions induces the overproduction of reactive oxygen species (ROS), such as superoxide radical $\left(\mathrm{O}_{2}^{-}\right), \mathrm{H}_{2} \mathrm{O}_{2}$ and hydroxyl radical $\left(\mathrm{HO}^{\circ}\right)$ in plant cells (Wise and Naylor, 1987). In addition, ROS are highly reactive to membrane lipids, protein and DNA. They are believed to be the major contributing factors to stress injuries and to cause rapid cellular damage (Afify et al., 2011; El-Beltagi, 2001, 2004, 2011; El-Beltagi et al., 2008, 2010, 2011 a,b; Kobeasy et al., 2011; Ibrahim et al., 2012; Mohamed, 2011; Mohamed et al., 2009; O'Kane et al., 1996), particularly when plants are exposed to stress conditions such as chilling stress, salt stress, iron deficiency, cadmium stress, lead toxicity, roasting, radiation, nematode infection, organisms and micro-organisms.

\section{Free oxygen and thiyl radicals}

Several reactive oxygen species (ROS) and one thiyl radical (RS') are known:

\section{Superoxide radical $\left(\mathrm{O}_{2}{ }^{\prime \prime}\right)$}

This ROS is formed when oxygen takes up one electron and as leaks in the mitochondrial electron transport but its formation is easily increased when exogenous components (redox cycling compounds) are presented. Its first production site is the internal mitochondrial membrane (NADH ubiquinone reductase and ubiquinone cytochrome $\mathrm{c}$ reductase). This species is reduced and forms hydrogen peroxide $\left(\mathrm{H}_{2} \mathrm{O}_{2}\right)$. The production of superoxide radicals at the membrane level (NADPH oxidase) is initiated in specialized cells (oxidative burst) with phagocytic functions (macrophages) and contributes to their bactericidal action (Fridovich, 1986).

$$
\mathrm{O}_{2}+\mathrm{e}^{-} \longrightarrow \mathrm{O}_{2}^{--} \quad \text { Superoxide radical }
$$

$$
\begin{aligned}
& \text { Hydrogen peroxide }\left(\mathrm{H}_{2} \mathrm{O}_{2}\right) \\
& \mathrm{O}_{2}^{-\cdot}+\mathrm{H}_{2} \mathrm{O} \longrightarrow \mathrm{HO}_{2}+\mathrm{OH}^{-} \text {Hydroperoxyl radi- } \\
& \mathrm{HO}_{2}+\mathrm{e}^{-}+\mathrm{H} \longrightarrow \mathrm{H}_{2} \mathrm{O}_{2} \text { Hydrogen peroxide }
\end{aligned}
$$$$
\text { cal }
$$

Hydrogen peroxide is mainly produced by enzymatic reactions. These enzymes are located in microsomes, peroxysomes and mitochondria. In plant and animal cells, superoxide dismutase is able to produce $\mathrm{H}_{2} \mathrm{O}_{2}$ by dismutation of $\mathrm{O}_{2}{ }^{-\prime}$, thus contributing to the lowering of oxidative reactions. The natural combination of dismutase and catalase contributes to remove $\mathrm{H}_{2} \mathrm{O}_{2}$ and thus has a true cellular antioxidant activity. $\mathrm{H}_{2} \mathrm{O}_{2}$ is also able to diffuse easily through cellular membranes.

\section{Hydroxyl radical $\left(\mathrm{OH}^{\cdot}\right)$}

In the presence of $\mathrm{Fe}^{2+}, \mathrm{H}_{2} \mathrm{O}_{2}$ produces the very active species $\mathrm{OH}$ by the Fenton reaction (described in 1894):

$\mathrm{Fe}^{2+}+\mathrm{H}_{2} \mathrm{O}_{2} \longrightarrow \mathrm{Fe}^{3+}+\mathrm{OH}^{-}+\mathrm{OH}^{-}$

This iron-catalyzed decomposition of oxygen peroxide is considered the most prevalent reaction in biological systems and the source of various deleterious lipid peroxidation products. It must be noticed that an important part of hydroxyl radicals is also produced (with $\mathrm{NO}_{2}$ ) by the decay of peroxinitrite or peroxynitrous acid.

\section{Nitric oxide (NO')}

Nitric oxide is produced in various types of cells and is well studied in vascular endothelium (O'Donnell and Freeman, 2001). While this species is not too reactive (poorly oxidizing function), even antioxidant under physiological concentrations (up to $100 \mathrm{nM}$ ), it reacts rapidly with oxygen to yield nitrogen dioxide $\left(\mathrm{NO}_{2}\right)$ which in turn may react with $\mathrm{NO}$ to yield nitrogen trioxide $\left(\mathrm{N}_{2} \mathrm{O}_{3}\right)$.

\section{Singlet oxygen $\left({ }^{1} \mathrm{O}_{2}\right)$}

This chemical form of oxygen is not a true radical but is reported to be an important ROS in reactions related to ultraviolet exposition. The presence of metals contributes to increase the production of singlet oxygen, as well as anion superoxide, and thus accelerates the oxidation of unsaturated lipids generating hydroperoxides. It has been suggested that singlet $\mathrm{O}_{2}$ may be formed during the degradation of lipid peroxides and thus may cause the production of other peroxide molecules. This singlet $\mathrm{O}_{2}$ formation may account for the chemiluminescence observed during lipid peroxidation.

\section{Ozone $\left(\mathrm{O}_{3}\right)$}

This natural compound present in the higher atmosphere and in the lower atmosphere of our polluted cities is a major pollutant formed by photochemical reactions between hydrocarbons and nitrogen oxides. Ozone is not a free radical but, as singlet oxygen, may produce them, stimulates lipid peroxidation and thus induces damages at the lipid and protein levels in vivo mainly in airways. Ozone may add on across a double bond and decomposes to form a free radical. The proposed mechanism is given below. 
46

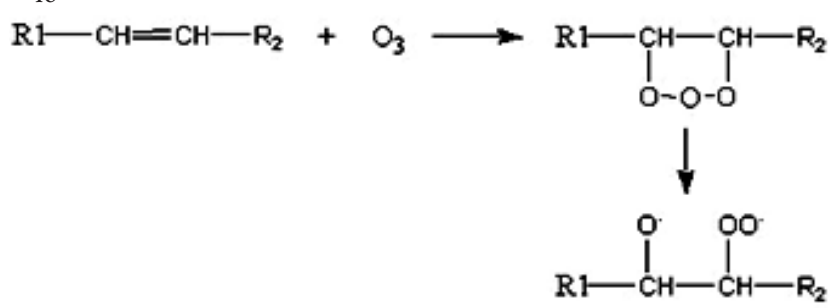

Thiyl radicals (RS*)

Aliphatic thiols ( $\mathrm{RSH}$ ) are contained in living organisms in high concentrations. The thiolate specie $\mathrm{RS}^{-}$is one of the most reactive functional groups found in proteins. It can react as a nucleophile and attack a disulfide bond. In the absence of oxygen, a thiyl radical was shown to induce cis/trans-isomerization of linoleic acid and led to several isomers (Ferreri et al., 2005). Thiol compounds (RSH) are frequently oxidized in the presence of iron or copper ions:

$\mathrm{RSH}+\mathrm{Cu}^{2+}--\rightarrow \mathrm{RS}^{\cdot}+\mathrm{Cu}^{+}+\mathrm{H}^{+}$

These thiyl radicals have strong reactivity in combining with $\mathrm{O}_{2}$ :

$\mathrm{RS}^{2}+\mathrm{O}_{2}--\rightarrow \mathrm{RSO}_{2}$

\section{Generation of lipid peroxidation products}

Several lipid molecules containing double bond(s) can be peroxidized under appropriate conditions. The primary products of lipid peroxidation being different forms have been demonstrated below (Fig. 1).

\section{INITIATION}

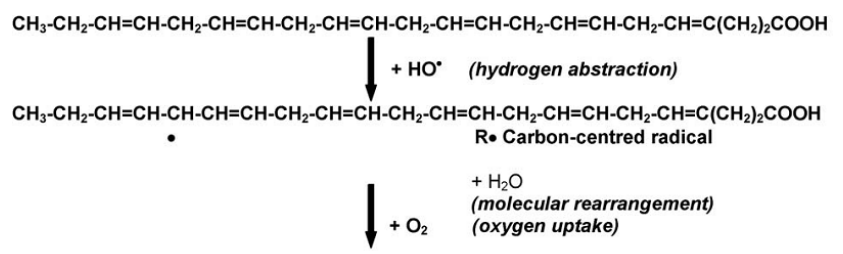

$\mathrm{CH}_{3}-\mathrm{CH}_{2}-\mathrm{CH}-\mathrm{CH}=\mathrm{CH}-\mathrm{CH}=\mathrm{CH}-\mathrm{CH}_{2}-\mathrm{CH}=\mathrm{CH}-\mathrm{CH}_{2}-\mathrm{CH}=\mathrm{CH}-\mathrm{CH}_{2}-\mathrm{CH}=\mathrm{CH}-\mathrm{CH}_{2}-\mathrm{CH}=\mathrm{C}\left(\mathrm{CH}_{2}\right)_{2}-\mathrm{COOH}$ O-O.

\section{PROPAGATION}

$\mathrm{CH}_{3}-\mathrm{CH}_{2}-\mathrm{CH}-\mathrm{CH}=\mathrm{CH}-\mathrm{CH}=\mathrm{CH}-\mathrm{CH}_{2}-\mathrm{CH}=\mathrm{CH}-\mathrm{CH}_{2}-\mathrm{CH}=\mathrm{CH}-\mathrm{CH}_{2}-\mathrm{CH}=\mathrm{CH}-\mathrm{CH}_{2}-\mathrm{CH}=\mathrm{C}\left(\mathrm{CH}_{2}\right)_{2}-\mathrm{COOH}$ O-O. Fatty acid peroxyl radical $+\mathrm{LH} \quad$ (interaction with other lipid molecule)

$\mathrm{CH}_{3}-\mathrm{CH}_{2}-\mathrm{CH}-\mathrm{CH}=\mathrm{CH}-\mathrm{CH}=\mathrm{CH}-\mathrm{CH}_{2}-\mathrm{CH}=\mathrm{CH}-\mathrm{CH}_{2}-\mathrm{CH}=\mathrm{CH}-\mathrm{CH}_{2}-\mathrm{CH}=\mathrm{CH}-\mathrm{CH}_{2}-\mathrm{CH}=\mathrm{C}\left(\mathrm{CH}_{2}\right)_{2}-\mathrm{COOH}$ $\mathrm{O}-\mathrm{OH}$ Fatty acid hydroperoxide
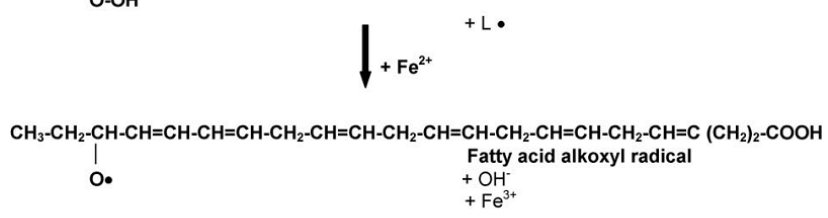

TERMINATION

$\mathrm{CH}_{3}-\mathrm{CH}_{2}-\mathrm{CH}-\mathrm{CH}=\mathrm{CH}-\mathrm{CH}=\mathrm{CH}-\mathrm{CH}_{2}-\mathrm{CH}=\mathrm{CH}-\mathrm{CH}_{2}-\mathrm{CH}=\mathrm{CH}-\mathrm{CH}_{2}-\mathrm{CH}=\mathrm{CH}-\mathrm{CH}_{2}-\mathrm{CH}=\mathrm{C}\left(\mathrm{CH}_{2}\right)_{2}-\mathrm{COOH}$ $\mathrm{O}-\mathrm{OH}$ Fatty acid hydroperoxide

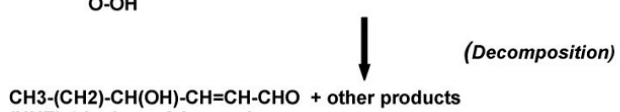
(HHE) 4-hydroxy-2-hexenal

Fig. 1. Lipid peroxidation of docosahexaenoic acid (22:6n-3)
Peroxidation offatty acids

As lipid peroxidation involves complex reactions and a great variety of substrates, understanding of these processes has come from studies of simple model substrates such as fatty acids of increasing unsaturation degree (the main fraction of membrane lipids) or cholesterol (abundant in blood plasma and cell membranes).

\section{Mechanisms of Fatty acid oxidation}

Three different mechanisms are able to induce lipid peroxidation:

1 - Autoxidation by free radical reaction

2 - Photo-oxidation

3 - Enzyme action

\section{Autoxidation}

Three different mechanisms are able to induce lipid peroxidation: autoxidation (by free radical reaction), photo-oxidation and enzyme action. Autoxidation is a radical-chain process involving 3 sequences, initiation, propagation and termination. The general process of lipid peroxidation consists of three stages: initiation, propagation and termination. Initiation occurs when oxygen is partly reduced by $\mathrm{Fe}^{2+}$ to species able to abstract a hydrogen atom from a methylene carbon. Resulting alkyl radical reacts rapidly with oxygen to form a peroxy radical ( $\mathrm{LOO}^{*}$ ), which itself can liberate $\mathrm{LOOH}$ via hydrogen abstraction from a neighbouring allyl bond. In this reaction, new alkyl radicals are produced which propagate lipid peroxidation.

$$
\begin{aligned}
& \mathrm{nFe}^{2+}+\mathrm{O}_{2} \longrightarrow \mathrm{nFe}^{3+}+\text { reduced } \mathrm{O}_{2}(\mathrm{I}) \\
& \mathrm{I}+\mathrm{LH} \longrightarrow \mathrm{IH}+\mathrm{L}^{2} \text { initiation } \\
& \mathrm{L}+\mathrm{O} \longrightarrow \mathrm{LOO} \\
& \mathrm{LOO}^{\circ}+\mathrm{LH} \longrightarrow \mathrm{LOOH}^{\circ} \text { L Propagation }
\end{aligned}
$$

$\mathrm{Fe}^{2+}$ can substantially enhance lipid peroxidation by decomposing $\mathrm{LOOH}$ to highly reactive lipid alkoxy radicals (LO) that behave as organic initiators and branch lipid peroxidation.

$$
\begin{aligned}
& \mathrm{Fe}^{2+}+\mathrm{LOOH} \longrightarrow \mathrm{Fe}^{3+}+\mathrm{OH}+\mathrm{LO} \\
& \mathrm{LO}+\mathrm{LH} \longrightarrow \mathrm{LOH}+\mathrm{L} \text { chain branching }
\end{aligned}
$$

Excess $\mathrm{Fe}^{2+}$ can also complete, as electron donors, for $\mathrm{LOO}^{\circ}$ and $\mathrm{LO}$ inhibiting both the propagation and chain branching reactions and causing the $\mathrm{Fe}^{2+}$ dependent termination of lipid peroxidation.

$$
\mathrm{Fe}^{2+}+\mathrm{LOO} / \mathrm{LO} \longrightarrow \mathrm{Fe}^{3+}+\mathrm{LOOH} / \mathrm{LOH} \text { termi- }
$$
nation

\section{Photo-oxidation}

As singlet oxygen $\left({ }^{1} \mathrm{O}_{2}\right)$ is highly electrophilic, it can react rapidly with unsaturated lipids but by a different mechanism than free radical autoxidation. In the presence of sensitizers (chlorophyll, porphyrins, myoglobin, riboflavin, bilirubin, erythrosine, rose bengal, methylene blue), a double bond interacts with singlet oxygen produced from $\mathrm{O}_{2}$ by light. Oxygen is added at either end carbon of a double bond which takes the trans configuration. 
Thus, one possible reaction of singlet $\mathrm{O}_{2}$ with a double bond between $\mathrm{C}_{12}$ and $\mathrm{C}_{13}$ of one fatty acid is to produce 12- and 13-hydroperoxides. The lifetime of singlet $\mathrm{O}_{2}$ in the hydrophobic cell membrane is greater than in aqueous solution. Furthermore, photo-oxidation is a quicker reaction than autoxidation since it was demonstrated that photo-oxidation of oleic acid can be 30000 times quicker than autoxidation and for polyenes photo-oxidation can be 1,000-1,500 times quicker (Frankel et al., 1979).

\section{Enzymatic peroxidation}

Enzymatic oxidation is another important type of oxidation. It has been known that lipoxygenase (LOX) and cyclooxygenase (COX) oxidize free and esterified polyunsaturated fatty acids, such as arachidonic acid (20:4 n-6), containing methylene interrupted double bonds into hydroperoxyeicosatetraenoic acid (HPETE), prostaglandins, prostacyclin, thromboxane and leukotrienes (Schneider $e t$ al., 2007). Until recently, lipoxygenases have been categorized to three major lipoxygenase isoforms with respect to their positional specificity of arachidonic acid oxygenation: 5-lipoxygenases, 12-lipoxygenases, 15-lipoxygenases. For example, 15-lipoxygenase oxidizes linoleates to give 13(S)-9-cis,11-trans-HPODE exclusively, while the free radicalmediated oxidation of linoleates gives four racemic products as shown in Fig. 2. LOX directly oxidizes phospholipids and cholesteryl esters in LDL particles as well as free fatty acids, although the specificity decreases (Kuhn, 2005; Noguchi et al., 2002). It is known also that cytochrome P-450 (CYP) oxidizes arachidonic acid to give hydroxyeicosatetraenoic acid (HETE), epoxyeicosatrienoic acid, and dihydroxyeicosatetraenoic acid (Roman, 2002).

\section{Cholesterol peroxidation}

Cholesterol has been exploited with great advantage to detect any oxidation process in cell membranes. In contrast with unsaturated fatty acids, cholesterol exists as a single molecular species, its oxidation products are thus much less complicated to isolate and characterize (Smith, 1981).

Cholesterol may undergo autoxidation and photooxidation, both processes give rise to oxysterols of various structures depending on the type of oxidation and the physical state of the substrate (Fig. 3). Thus, the identification of cholesterol oxidation products may be used as a mechanistic proof in various oxidant systems. When cholesterol esters are oxidized, the structure and the yield of the formed oxysterols depend on the fatty acid species. An extensive review on oxysterols, including their analysis, formation, occurrence, metabolism and physiological actions, may be consulted for further information (Schroepfer, 2000). Phytosterols may undergo oxidative processes comparable to those involved in cholesterol oxidation but the amount of biological research on oxyphytosterols is yet scarce (Hovenkamp et al., 2008).

\section{Autoxidation}

The main reaction involved in oxidative deterioration of cholesterol, is a self-catalytic reaction with molecular oxygen. Cholesterol autoxidation usually starts at C-7 by abstraction of hydrogen following the addition of an oxygen molecule forming primary COP, isomers of 7-hydroperoxycholesterol (7-OOHCh). These 7- hydroperoxycholesterols can further convert into $7 \alpha$-hydroxycholesterol $(7 \alpha-\mathrm{OHCh})$ and $7 \beta-$ hydroxycholesterol $(7 \beta-\mathrm{OHCh})$, which are commonly found in food.

Both isomeric 7-hydroperoxycholesterol can also undergo dehydration during heating forming 7-ketocholesterol (7-KCh). In addition, 7-ketocholesterol can be formed by dehydration of isomeric 7-hydroxycholesterol in the presence of radicals. 7- ketocholesterol is also considered as a major COP in food matrix. Formation of isomeric epoxy cholesterols occurs due to interaction between cholesterol and hydroxy radical and these epoxy compounds can be hydrolyzed in acidic medium convert-

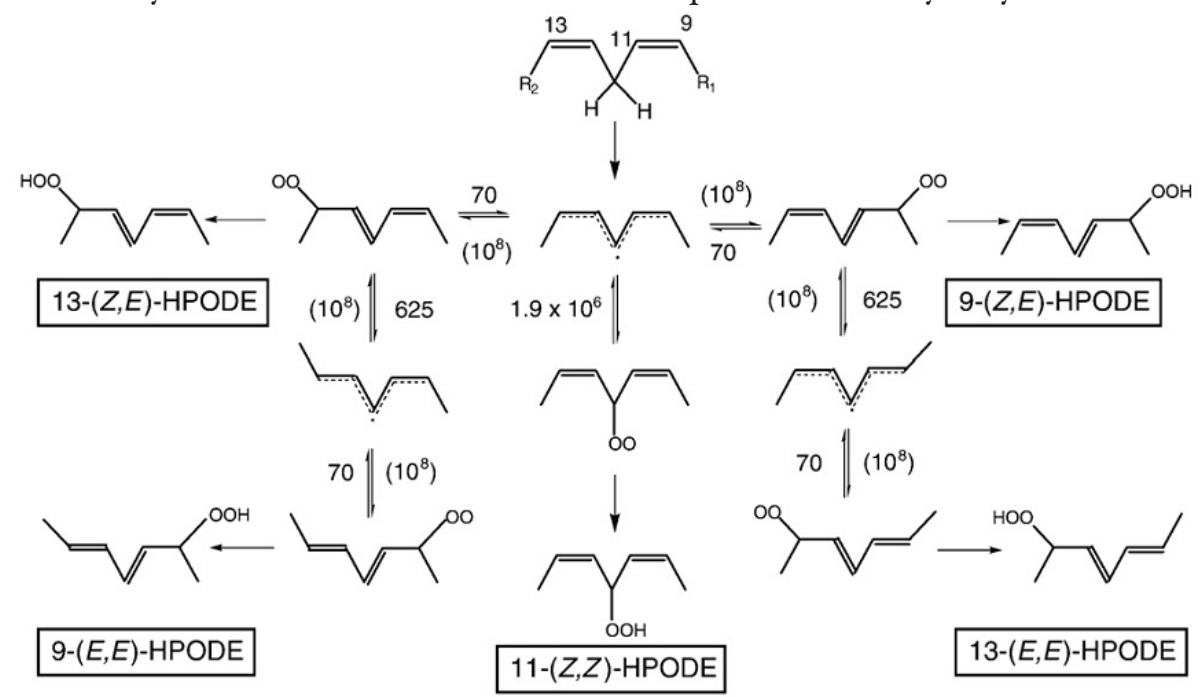

Fig. 2. Mechanism of peroxidation of linoleates 
48

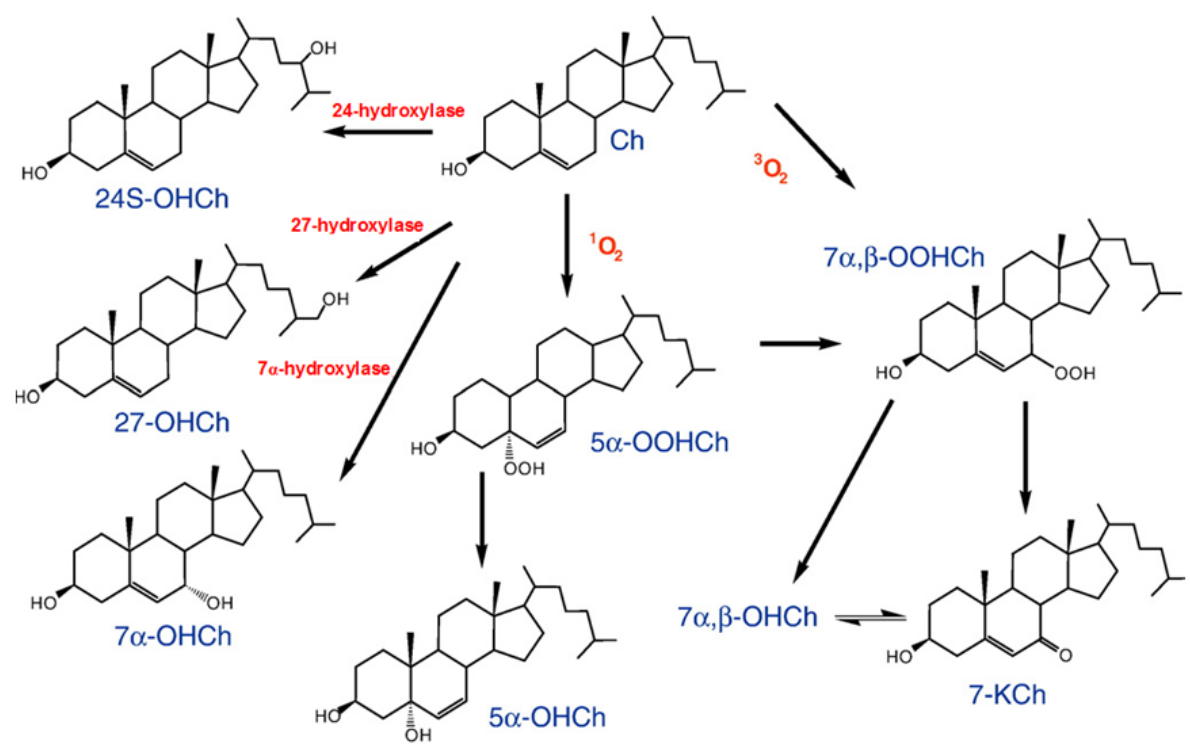

Fig. 3. Major pathways of cholesterol oxidation

ing them into most toxic triols. The side chain oxidation occurs at C- 20 and C-25 positions resulting in the production of relevant hydroperoxide, 20 - hydroperoxide and 25-hydroperoxide respectively, which can further reduce into $20 \alpha$-hydroxycholesterol and 25-hydroxy cholesterol.

\section{Photoxidation}

In photoxidation of cholesterol, single oxygen is formed from triplet oxygen by light in the presence of an active sensitizer (natural pigment or synthetic colorant). Cholesterol can react with singlet oxygen in the presence of photo-sensitizer, forming dominant hydroperoxide at C-5. A part of this hydroperoxide converts into $5 \alpha$-hydroxycholesterol and the other part of the 5-hydroperoxide ( $5-\mathrm{HOOCh}$ ) is further converted into stable 7-hydroxiperoxide and 6- hydroperoxide that are present in minor amounts. 7-hydroperoxides can be converted into isomeric 7-hydroxycholesterol and into 7-ketocholesterol at the same time 5-hydroxycholesterol (5- $\mathrm{HOCh}$ ) can be formed.

\section{Enzymatic oxidation}

Some enzymes in food oxidize cholesterol. Available reports show that the conversion of $5 \alpha$-hydroperoxides
( $5 \alpha-\mathrm{HPC})$ into $7 \alpha-\mathrm{HPC}$, epimerization of $7 \alpha-\mathrm{HPC}$ into $7 \beta$-HPC, and formation of 7 -HC epimers from the corresponding hydroperoxides occur by enzymatic reactions. But this has to be studied to a further extent due to the fact that these products can be formed by the usual non-enzymatic reactions. Monooxygenase, dioxygenase, dehydrogenase and oxidases are the main enzymes that can oxidize cholesterol. The COP, $7 \alpha$-hydroxycholesterol, 24- hydroxycholesterol, 25-hydroxycholesterol, 20 $\alpha$-hydroxycholesterol, (25R)-26-hydroxycholesterol, 22Rhydroxycholesterol, 27- hydroxycholesterol are produced by enzymatic oxidation of cholesterol (Brown, 2009).

\section{Analytical methods for studying lipid peroxidation}

Damage to lipids alters and modifies cellular membranes and, therefore, cellular function. Lipid peroxidation is a complex process consisting of three stages: initiation, propagation, and termination (Halliwell and Gutteridge, 1999). For each stage, there are many available methods to quantify the progress of the process and same of them are included in Tab. 1.

Tab. 1. Analytical methods for studying lipid peroxidation in membranes

\begin{tabular}{|c|c|}
\hline $\begin{array}{l}\text { Measurement of the lipid content: loss of substrates, like unsaturated fatty acyl chains } \\
\text { in different lipid molecules, before and following exposure to prooxidants }\end{array}$ & $\begin{array}{l}\text { Guajardo et al. (2002); } \\
\text { Gavazza and Catala (2006) }\end{array}$ \\
\hline $\begin{array}{l}\text { Measurement of oxygen consumption during the propagation stage UV } \\
\text { absorption of conjugated diene hydro peroxides at } 234 \mathrm{~nm} \text {. } \\
\text { Among the many methods devised for measurement of peroxide formation during the process, some } \\
\text { reveal total peroxide formation, while some determine specific peroxide, which can indicate the fatty acyl } \\
\text { chain undergoing the peroxidation process. Spectrophotometric determination of the iodine liberated } \\
\text { when lipid hydroperoxides oxidise iodide ions has long been found more convenient than titration }\end{array}$ & $\begin{array}{l}\text { Raveh et al. (2002) } \\
\text { Sloane et al. (1991) } \\
\text { Buege and Aust (1978) }\end{array}$ \\
\hline $\begin{array}{l}\text { In the last step of the peroxidation process, peroxides are decomposed to aldehydes like malondialdehyde (MDA), } \\
\text { which can be detected by thiobarbituric acid that gives a pink color easily measurable. The end products of other } \\
\text { aldehydes, e.g., hexanal, can also be measured. All of these are termed thiobarbituric reactive species (TBARS) }\end{array}$ & Esterbauer (1996) \\
\hline $\begin{array}{l}\text { Isoprostanes, neuroprostanes, and isofuranes are determined by GC/MS Some lipid peroxidation products } \\
\text { are light-emitting species and their chemiluminescence can be used as an internal marker of oxidative stress }\end{array}$ & Roberts and Fessel (2004) \\
\hline
\end{tabular}




\section{Defense mechanisms}

\section{Antioxidant enzymes}

\section{Superoxide dismutase}

Superoxide dismutase (SOD, 1.15.1.1) was first isolated by Mann and Kleilin (1938) and thought to be a copper storage protein. Subsequently, the enzyme was identified by a number of names, erythrocuprein, indophenol oxidase, and tetrazolium oxidase until its catalytic function was discovered by McCord and Fridovitch (1969). SOD is now known to catalyse the dismutation of superoxide to hydrogen peroxide and oxygen:

$$
\begin{aligned}
& \mathrm{O}_{2}{ }^{-\cdot}+\mathrm{O}_{2}{ }^{-\cdot}+ \text { Superoxide dismutase } \\
& 2 \mathrm{H}^{+} \\
& \text {Mn-SOD: } \mathrm{H}_{2} \mathrm{O}_{2}+\mathrm{O}_{2} \\
& \text { Fe-SOD: chlochondria } \\
& \text { CuZn-SOD: chloroplast } \\
& \text { CuZn-SOD: cytosol }
\end{aligned}
$$

Therefore, the activity of this enzyme determines the relative proportions of the two constituents of the Haber-Weiss reaction that generates hydroxyl radicals. Since SOD is present in all aerobic organisms and most (if not all) subcellular compartments that generate activated oxygen, it has been assumed that SOD has a central role in the defense against oxidative stress (Scandalias, 1993). There are three distinct types of SOD classified on the basis of the metal cofactor: the copper/zinc ( $\mathrm{Cu} / \mathrm{Zn}$ - SOD), the manganese (Mn-SOD) and the iron (Fe-SOD) isozymes. The Mn-SOD is found in the mitochondria of eukaryotic cells; some $\mathrm{Cu} / \mathrm{Zn}-\mathrm{SOD}$ isozymes are found in the cytosol, others in the chloroplasts of higher plants. The FeSOD isozymes are often not detected in plants, but when detected, Fe-SOD is usually associated with the chloroplast compartment (Bowler et al., 1992).

\section{Catalase}

\section{Catalase}

$2 \mathrm{H}_{2} \mathrm{O}_{2} \longrightarrow 2 \mathrm{H}_{2} \mathrm{O}+\mathrm{O}_{2}$

Catalase (CAT, 1.11.1.6) is a heme-containing enzyme that catalyses the dismutation of hydrogen peroxide into water and oxygen. The enzyme is found in all aerobic eukaryotes and is important in the removal of hydrogen peroxide generated in peroxisomes by oxidases involved in B-oxidation of fatty acids, the glyoxylate cycle (photorespiration) and purine catabolism. All forms of the enzyme are tetramers in excess of 220,000 molecular weights. Cat- 1 and cat -2 are localized in peroxisomes and the cytosol, whereas cat-3 is mitochondrial. It is interesting in this regard to note that catalase is very sensitive to light and has a rapid turnover rate similar to that of the D1 protein of PSII (Hertwig et al., 1992). Regardless, stress conditions which reduce the rate of protein turnover, such as salinity, heat shock or cold, cause the depletion of catalase activity (Hertwig et al., 1992). This may have significance in the plant's ability to tolerate the oxidative components of these environmental stresses.
Guaiacol peroxidase

Guaiacol peroxidase (GPX, 1.11.1.7), a heme containing protein, preferably oxidizes aromatic electron donor such as guaiacol and pyragallol at the expense of $\mathrm{H}_{2} \mathrm{O}_{2}$. It is widely found in animals, plants, and microbes. These enzymes have four conserved disulfide bridges and contain two structural $\mathrm{Ca}^{2+}$ ions (Schuller et al., 1996). Many isoenzymes of GPX exist in plant tissues localized in vacuoles, the cell wall, and the cytosol (Asada, 1992). GPX is associated with many important biosynthetic processes, including lignification of cell wall, degradation of IAA, biosynthesis of ethylene, wound healing, and defense against abiotic and biotic stresses (Kobayashi et al., 1996). GPXs are widely accepted as stress "enzyme." GPX can function as effective quencher of reactive intermediary forms of $\mathrm{O}_{2}$ and peroxy radicals under stressed conditions (Vangronsveld and Clijsters, 1994). Various stressful conditions of the environment have been shown to induce the activity of GPX (Mishra et al., 2013; Moussa and Abdel-Aziz, 2008; Radotic et al., 2000). Radotic et al. (2000) correlated increased activity of GPX to oxidative reactions under metal toxicity conditions and suggested its potential as biomarker for sublethal metal toxicity in plants. Recently, Tayefi-Nasrabadi et al. (2011) also concluded that greater protection of salt-tolerant safflower plants from salt-induced oxidative damage results, at least in part, through the increase of the GPX activity, catalytic efficiency and induction of specific isoenzymes compared to salt-sensitive cultivar.

\section{Glutathione peroxidase}

Glutathione peroxidase (GPx, 1.11.1.9) is a seleniumdependent enzyme, which decomposes $\mathrm{H}_{2} \mathrm{O}_{2}$ and various hydro- and lipid peroxides (Kinnula et al., 1995). The classical form of GPx is cellular and dispersed throughout the cytoplasm, but GPx activity is also found in mitochondria (Buettner, 1998). Extracellular form of GPx is genetically distinct from cellular GPx (Yoshimura et al., 1994) and has been detected in several human tissues, including lung (Chu et al., 1992). Selenium is essential for the protein synthesis and enzymatic activity of GPx. Severe selenium deficiency may cause liver necrosis and degenerative heart disease (Buettner, 1998). GPx requires reduced glutathione as a co-substrate, and the role of glutathione reductase is to restore glutathione from an oxidised to a reduced form (Kinnula et al., 1995).

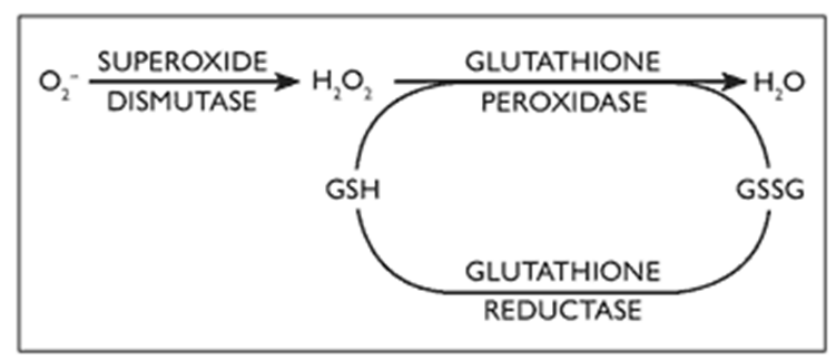


50

\section{Ascorbate peroxidase}

Ascorbate peroxidase (APX, EC 1.1.11.1) is a central component of AsA-GSH cycle, and plays an essential role in the control of intracellular ROS levels. APX uses two molecules of AsA to reduce $\mathrm{H}_{2} \mathrm{O}_{2}$ to water with a concomitant generation of two molecules of MDHA. APX is a member of Class I super family of heme peroxidases and is regulated by redox signals and $\mathrm{H}_{2} \mathrm{O}_{2}$ (Patterson and Poulos, 1995; Welinder, 1992). Based on amino acid sequences, five chemically and enzymatically distinct isoenzymes of APX have been found at different subcellular localization in higher plants. These are cytosolic, stromal, thylakoidal, mitochondrial and peroxisomal isoforms (Madhusudhan et al., 2003; Nakano and Asada, 1987; Sharma and Dubey, 2004). APX found in organelles scavenges $\mathrm{H}_{2} \mathrm{O}_{2}$ produced within the organelles, whereas cytosolic APX eliminates $\mathrm{H}_{2} \mathrm{O}_{2}$ produced in the cytosol, apoplast or that diffused from organelles (Mittler and Zilinskas, 1992). The chloroplastic and cytosolic APX isoforms are specific for AsA as electron donor and the cytosolic isoenzymes are less sensitive to depletion of AsA than the chloroplastic isoenzymes, including stromal and thylakoid bound enzymes (Ishikawa et al., 1998; Sharma and Dubey, 2004).

\section{Antioxidant compounds}

\section{Ascorbic acid}

L-ascorbic acid (vitamin C) is an important vitamin in the human diet and is abundant in plant tissues. Green leaves have the same amount of ascorbate as chlorophyll. Ascorbate has been shown to have an essential role in several physiological processes in plants, including growth, differentiation and metabolism (Foyer, 1993). Ascorbate functions as a reductant for many free radicals, thereby minimizing the damage caused by oxidative stress.

L-ascorbic acid is synthesized from hexose sugars in higher plants but controversy remains concerning some steps in its synthesis (Loewus, 1988). Although two distinct pathways are possible, higher plants primarily convert $\mathrm{D}$-glucose to ascorbate by a direct conversion that maintains the carbon chain in the same sequence. Ascorbate can directly scavenge oxygen free radicals with and without enzyme catalysts and can indirectly scavenge them by recycling tocopherol to the reduced form. By reacting with activated oxygen more readily than any other aqueous component, ascorbate protects critical macromolecules from oxidative damage.

Antioxidant effects of vitamins $\mathrm{C}$ and $\mathrm{E}$ on lipid peroxidation (LPO). The LPO chain reaction can be initiated by many radical species (indicated by $\mathrm{R}^{\bullet}$ ) and converts LH into LOO', which attacks another LH generating $L^{-}$(paths 1 and 2, dotted oval). Ascorbic acid may scavenge the initiating radical species $\mathrm{R}^{\bullet}$ and reduce the tocopheroxyl radical, generating the ascorbyl radical, which can be reduced by glutathione-dependent enzymes. Key to reaction steps: 1 , initiating event; 2 , radical propagation reaction; 3 , termination of the radical reaction by tocopherol (TocH); 4, dismutation of ascorbyl radicals (Asc $\bullet-$ ); 5 , reduction of dehydroascorbate (DHAsc) by GSH-dependent dehydroascorbate reductase; $6, \mathrm{GSH}$ peroxidase (GPx); 7, further oxygenation and nonenzymatic cleavage of carbon-carbon bonds yields 4-hydroperoxy-2(E)-nonenal (HPNE); 8, reduction yields 4-hydroxy-2(E)-nonenal (HNE) (Fig. 4).

Ascorbate will react with superoxide, hydrogen peroxide or the tocopheroxyl radical to form monodehydroascorbic acid and/or dehydroascorbic acid. The reduced forms are recycled back to ascorbic acid by monodehydroascorbate reductase and dehydroascorbate reductase using reducing equivalents from NAD $(\mathrm{P}) \mathrm{H}$ or glutathione, respectively. Dehydroascorbate may decompose into tartrate and oxalate. Ascorbate has been found in the chloroplast, cytosol, vacuole and extra-cellular compartments of the cell.

\section{Glutathione}

Glutathione (GSH) is a tripeptide (Glu-Cys-Gly) whose antioxidant function is facilitated by the sulphydryl group of cysteine (Fig. 5). On oxidation, the sulphur forms a thiyl radical that reacts with a second oxidized glutathione forming a disulphide bond (GSSG).

GSH is found in most tissues, cells and subcellular compartments of higher plants. GSH concentration is highest in the chloroplast, averaging between 1 and 4 $\mathrm{mM}$, but significant quantities also accumulate in the cy-

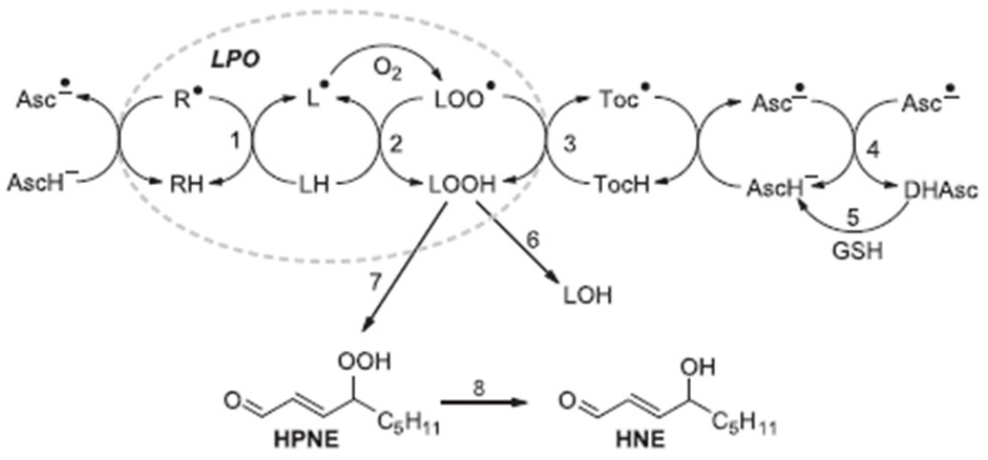

Fig. 4. Ascorbic acid may scavenge the initiating radical species $R^{\bullet}$ and reduce the tocopheroxyl radical 


\section{glutathione (GSH)}<smiles>COC(=O)[C@H](N)CCC(=O)NC(CS)C(=O)NCC(=O)[O-]</smiles>

Fig. 5. structure of glutathione

tosol. GSH can function as an antioxidant in many ways. It can react chemically with singlet oxygen, superoxide and hydroxyl radicals and therefore function directly as a free radical scavenger. GSH may stabilize membrane structure by removing acyl peroxides formed by lipid peroxidation reactions (Price et al., 1990). GSH is the reducing agent that recycles ascorbic acid from its oxidized to its reduced form by the enzyme dehydroascorbate reductase (Loewus, 1988).

There are alternative functions for GSH in cellular metabolism independent of its antioxidant properties. It may have a significant role in the transport of reduced sulphur from leaves to sink tissues such as the root (Rennenberg, 1982). GSH also participates in the detoxification of xenobiotics as a substrate for the enzyme glutathione-S-transferase. GSH is also the precursor of the phytochelatins that act as heavy metal binding peptides in plants. The enzymes that catalyse the synthesis and degradation of GSH have been characterized in both the chloroplastic and cytosolic compartments (Timmerman, 1989).
Tocopherol

The tocopherols, specifically $\alpha$-tocopherol (vitamin E) has been found in all higher plants, in both photosynthetic and non-photosynthetic tissues. Although tocopherol is a well documented component of chloroplast membranes, there are no quantitative estimates of its distribution among other plant cell membranes. $\alpha$-Tocopherol is well established as a membrane stabilizing agent. Although some of this activity is due to its influence on membrane lipid organization, at least part of this activity is the result of its ability to complex free fatty acids (Fryer, 1992).

Vitamin E is a natural, highly tolerable and cost effective molecule. This generic term is used for tocopherol and tocotrienols consisting of two rings with a hydrocarbon chain. Both structures are similar, although the tocotrienol structure has double bonds on the isoprenoid units. Natural vitamins Es are known as $\alpha, \beta, \gamma$, and $\delta$ according to the methyl or proton groups that are bound to their Benzene rings and the most common and biologically active form is alpha-tocopherol (Fig. 6) (Brigelius-Flohe and Traber,

\section{Vitamin $E$}<smiles>[R2]c1c(C)c([R2])c2c(c1C)O[C@]([R3])(C)CC2</smiles>

\begin{tabular}{|c|c|c|c|}
\hline & $\mathrm{R}_{1}$ & $\mathrm{R}_{2}$ & $\mathrm{R}_{3}$ \\
\hline$\alpha$-Tocopherol & $\mathrm{CH}_{3}$ & $\mathrm{CH}_{3}$ & $\mathrm{C}_{16} \mathrm{H}_{33}$ \\
\hline$\beta$-Tocopherol & $\mathrm{CH}_{3}$ & $\mathrm{H}$ & $\mathrm{C}_{16} \mathrm{H}_{33}$ \\
\hline$\gamma$-Tocopherol & $\mathrm{H}$ & $\mathrm{CH}_{3}$ & $\mathrm{C}_{16} \mathrm{H}_{33}$ \\
\hline$\delta$-Tocopherol & $\mathrm{H}$ & $\mathrm{H}$ & $\mathrm{C}_{16} \mathrm{H}_{33}$ \\
\hline
\end{tabular}

Fig. 6. Structures of vitamin E. The tocopherol series has the phytyl side chain (R3), whereas in the tocotrienols the side chain has double bonds at the 3', 7', and 11 ' positions 
52

1999). When produced synthetically, it is composed of eight stereoisomers in which RRR- $\alpha$-tocopherol is the most biologically active form (Sies and Murphy, 1991). While the recommended daily allowance (RDA) for vitamin $\mathrm{E}$ is $8 \mathrm{mg}$ (12 IU) for females and $10 \mathrm{mg}$ (15 IU) for males, Packer (1991) recommends up to 1,000-1,200 IU intake of vitamin $\mathrm{E}$ in some pathologies including cataract. The principal reserve of natural vitamin $\mathrm{E}$ is vegetable oil where its function is to protect tissue from oxidative damage. It is a liposoluble molecule, and, therefore, after dietary intake, vitamin $\mathrm{E}$ is not only absorbed easily from the intestinal lumen but is also dispersed between lipids and proteins in cell membranes. Vitamin E molecules can interrupt free radical chain reactions by capturing the free radical. This imparts to them their antioxidant properties. The free hydroxyl group on the aromatic ring is responsible for the antioxidant properties. The hydrogen from this group is donated to the free radical, resulting in a relatively stable free radical form of vitamin E (Fig. 7, 8) (Sies and Murphy, 1991).

\section{Carotenoids}

Carotenoids are $\mathrm{C}_{40}$ isoprenoids and tetraterpenes that are located in the plastids of both photosynthetic and non-photosynthetic plant tissues. In chloroplasts, the carotenoids function as accessory photosynthetic pigments in light harvesting, but perhaps a more important role is their ability to detoxify various forms of activated oxygen and triplet chlorophyll that are produced as a result of ex- citation of the photosynthetic complexes by light. Based on their composition, carotenoids are divided in two classes, carotenes containing only carbon and hydrogen atoms, and oxocarotenoids (xanthophylls) which carry at least one oxygen atom. Carotenoids are synthesised from geranylpyrophosphate from the isoprenoid pathway in plastids, and thus have common precursors to chlorophyll and tocopherol. In terms of its antioxidant properties carotenoids can protect the photosystems in one of four ways: by reacting with lipid peroxidation products to terminate chain reactions (Burton and Ingold, 1984); by scavenging singlet oxygen and dissipating the energy as heat (Mathis and Kleo, 1973); by reacting with triplet or excited chlorophyll molecules to prevent formation of singlet oxygen; or by the dissipation of excess excitation energy through the xanthophyll cycle. Most carotenoids contain an extended system of conjugated double bonds, which is responsible for their antioxidant activity (Fig. 9).

\section{Phenolic Compounds and Their Functions}

Phenolics are characterized by at least one aromatic ring $\left(\mathrm{C}_{6}\right)$ bearing one or more hydroxyl groups. They are mainly synthetized from cinnamic acid, which is formed from phenylalanine by the action of L-phenyloalanine ammonia-lyase PAL (EC 4.3.1.5), the branch point enzyme between primary (shikimate pathway) and secondary (phenylopropanoid) metabolism. Phenols are divided into several different groups, distinguished by the number

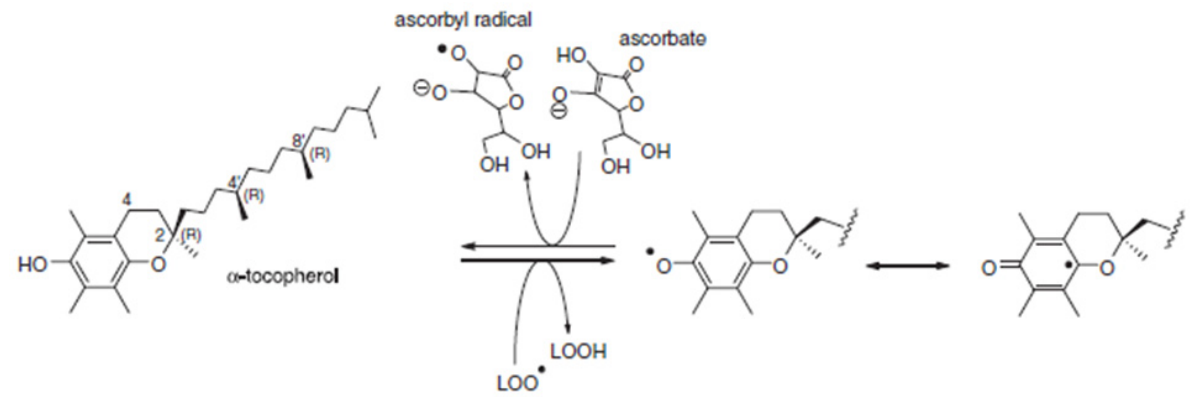

Fig. 7. Antioxidant effect of vitamin E. $\alpha$-Tocopherol reacts with a lipid hydroperoxyl $\left(\mathrm{LOO}^{*}\right)$ radical. The resultant tocopheryl radical is resonance-stabilized and does not react with oxygen (unlike $L \cdot$ radicals) and it can be converted back to $\alpha$-tocopherol by ascorbate

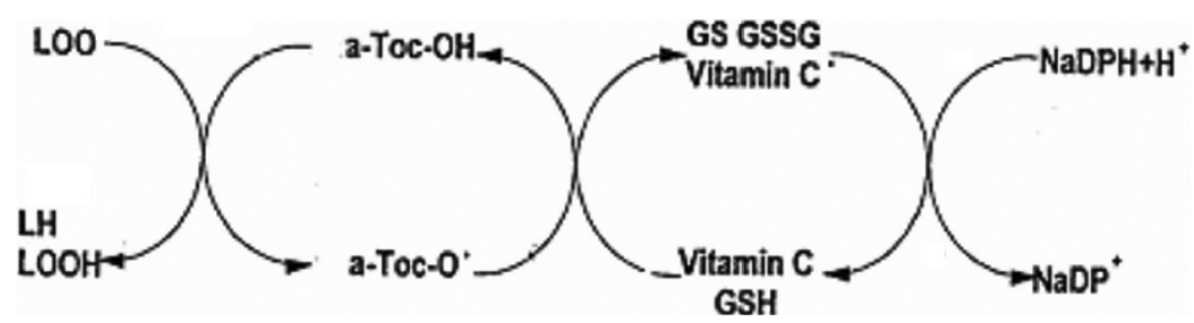

Fig. 8. Antioxidant mechanism of tocopherols. LH: Lipid molecule, LOOH: Lipid peroxide, LOO+: Lipid Peroxide radical, a-Toc-OH: $\alpha$-Tocopherol, a-Toc-O+: $\alpha$-Tocopherol radical, GSH: Glutathione, Vitamin C+: Vitamin C radical, GS+: Glutathione radical, GSSG: Oxidized glutathione, NADPH: Reduced nicotinamide adenine dinucleotide phosphate, $\mathrm{NADP}+$ : Oxidized nicotinamide adenine dinucleotide phosphate 

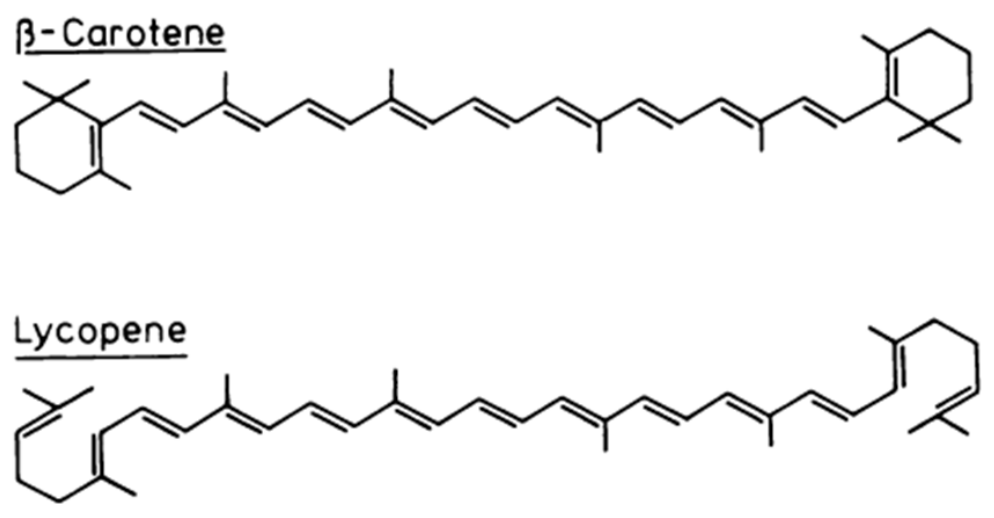

Fig. 9. Structures of $\beta$-Carotene and Lycopene

of constitutive carbon atoms in conjunction with the structure of the basic phenolic skeleton (simple phenols, benzoic acids, phenylopropanoids and flavonoids) (Rice-Evans et al., 1997). Phenolics are diverse secondary metabolites (flavonoids, tannins, hydroxycinnamate esters and lignin) abundant in plant tissues (Grace and Logan, 2000). Polyphenols possess ideal structural chemistry for free radical scavenging activity, and they have been shown to be more effective antioxidants in vitro than tocopherols and ascorbate. Antioxidative properties of polyphenols arise from their high reactivity as hydrogen or electron donors, and from the ability of the polyphenol-derived radical to stabilize and delocalize the unpaired electron (chain-breaking function), and from their ability to chelate transition metal ions (termination of the Fenton reaction) (Rice-Evans et al., 1997). Another mechanism underlying the antioxidative properties of phenolics is the ability of flavonoids to alter peroxidation kinetics by modification of the lipid packing order and to decrease fluidity of the membranes (Arora et al., 2000). These changes could sterically hinder diffusion of free radicals and restrict peroxidative reactions.

\section{Flavonoids}

Like as phenolic acids, flavonoids are secondary metabolites of plants with polyphenolic structure. They are synthesized by the polypropanoid pathway and the start up component is phenylalanine molecule. The biological effects of these compounds vary. All flavonoids share the basic C6-C3-C6 structural skeleton, consisting of two aromatic $\mathrm{C}_{6}$ rings $(\mathrm{A}$ and $\mathrm{B})$ and a heterocyclic ring $(\mathrm{C})$ that contains one oxygen atom. They have been classified into six subgroups:

1. Flavones (luteonin, apigenin, tangeritin).

2. Flavonols (quercetin, kaemferol, myricetin, isorhamnetin, pachypodol).

3. Flavanones (hesteretin, naringenin, eriodictyol).

4. Flavan-3-ols: catechins and epicatechins.

5. Isoflavones (genistein, daidzein, glycitein).

6. Anthocyanidins compounds (cyanidin, delphinidin, malvidin, pelargonidin, peonidin, petunidin).
Other common flavonoid groups include aurones, xanthones, and condensed tannins. The catechins and leucoanthocyanidins are structurally similar and only rarely exist as their glycosides. Most of flavonoids are present in our daily life (Manach et al., 2004). To date, about 6,000 flavonoid compounds have been isolated and identified, and many are common in higher plants (Austin and Noel, 2003). Most flavonoid compounds which are often accumulated in the vacuoles of plant cells are glycosides. Glycosides can either be $\mathrm{O}$ - or $\mathrm{C}$ - linked. The variant of flavonoid glycosides are based on the number of positions on the flavonoid for glycosylation, the level of glycosylation and the number of types of sugars involved in glycosylation. Furthermore, of the several hundred aglycones isolated from plants, only eight are distributed widely (Seigler, 1998) and the eight most common flavonoid nuclei are kaempferol, quercetin, rutin, catechin, epicatechin, myricetin, anthocyanidins and luteolin.

Flavonoids are well known for their antioxidant activity. Antioxidants are specific compounds that protect human, animal and plant cells against the damaging effects of free radicals (reactive oxygen species, ROS). An imbalance between antioxidants and free radicals results in oxidative stress, will/may lead to cellular damage (Kukic et al., 2006). At present, most antioxidants are manufactured synthetically, belonging to the class of synthetic antioxidants. The main disadvantage of synthetic antioxidants is the side effects when consumed in vivo (Chen et al., 1992). Plants are potential sources of invaluable antioxidants. Natural or phytochemical antioxidants are secondary metabolites in plants (Dai and Mumper, 2010) such as phenolic acids, flavonoids and carotenoids, which are amongst the antioxidants produced by plants for their sustenance (Apak et al., 2007). Recently, phenolics and flavonoids have been considered as great antioxidants and proved to be more effective than Vitamin C, E and carotenoids (Dai and Mumper, 2010). The antioxidant properties of phenolic and flavonoid compounds are mediated by the following mechanisms: (1) scavenging radical species such as ROS/ reactive nitrogen species (RNS); (2) suppressing ROS/RNS formation by inhibiting some enzymes or chelating trace metals involved in free radical production; (3) up regulat- 
54

ing or protecting antioxidant defense (Cotelle, 2001). The reduction activity of phenolic and flavonoid compounds depends on the number of free hydroxyl groups in the molecular structure, which would be strengthened by steric hindrance (Rice-Evans et al., 1996).

\section{Future perspectives of antioxidants}

During the past decades a lot of research has been carried out around antioxidants and their effects on health. There is a lack of standard procedure to determine antioxidant activity across the majority of matrixes in order to produce consistent and undoubted results. The published results so far are conflicting and difficult to compare between each other. The antioxidant limitations and metabolism still pose a challenge to future research in this field, and researchers must try and overcome these drawbacks.

The new trends in antioxidant treatments include compounds that behave like the enzyme SOD in order to alleviate acute and chronic pain related to inflammation and reperfusion. Another promising research area is genetics, which aim to breed genetically modified plants that can produce higher quantities of specific compounds, yielding higher quantities of antioxidants (Devasagayam $e t$ al., 2004). Suntres (2011) theorizes that antioxidant liposomes will hold an important role in future research on antioxidants. This author reports that they can facilitate antioxidant delivery to specific sites as well as achieving prophylactic and therapeutic action.

Bouayed and Bohn (2010) postulate that the balance between oxidation and antioxidation is critical in maintaining a healthy biologic system. Low doses of antioxidants may be favorable to this system, but high quantities may disrupt the balance. The main conclusion is that antioxidants do have an impact on our health, but the big question is the method of administration (food vs. supplements) and quantity that might be debatable. The fact that potent antioxidants in vitro may not have any effect in vivo should not discourage further research but rather stimulate it (Devasagayam et al., 2004).

It is true that antioxidants are beneficial and display a useful role in human homeostasis, but so are prooxidants; the academic community should search deeper into the kinetics and in vivo mechanisms of antioxidants to uncover the optimal concentrations or desired functions in order to push forward against cancer, neurodegenerative and cardiovascular diseases.

\section{References}

Afify AMR, El-Beltagi HS, Fayed SA, Shalaby EA (2011). Acaricidal activity of successive extracts from Syzygium cumini L. Skeels (Pomposia) against Tetranychus urticae Koch. Asian Pac J Trop Biomed 1(5):359-364.

Apak R, Guclu K, Demirata B, Ozyurek M, Esin CS, Bektasoglu B, Berker K, Ozyur D (2007). Comparative evaluation of various total antioxidant capacity assays applied to phenolic compounds with the CUPRAC assay. Molecules 12:1496547.

Arora A, Byrem TM, Nair MG, Strasburg GM (2000). Modulation of liposomal membrane fluidity by flavonoids and isoflavonoids. Arch Biochem Biophys 373:102-109.

Asada K (1992). Ascorbate peroxidase: a hydrogen peroxide scavenging enzyme in plants. Physiol Plant 85(2):235-241.

Austin MB, Noel JP (2003). The chalcone synthase superfamily of type III polyketide synthases. Nat Prod Rep 20:79-110.

Bouayed J, Bohn T (2010). Exogenous antioxidants-doubleedged swords in cellular redox state. Oxid Med Cell Longev 3:228-237.

Bowler C, van Montague M, Inzé D (1992). Superoxide dismutase and stress tolerance, Ann Rev Plant Physiol Plant Mol Biol 43:83-116.

Brigelius-Flohe R, Traber MG (1999). Vitamin E: Function and metabolism. FASEB J 13:1145-1155.

Brown AJ (2009). 24(S), 25-Epoxycholesterol, a messenger in cholesterol homeostasis. Int J Biochem Cell Biol 41:744747.

Buege JA, Aust SA (1978). Microsomal lipid peroxidation. Methods Enzymol 52:302-310.

Buettner GR (1998). Antioxidant enzymes and functions. Naturally occurring antioxidants. Oxygen '98, Washington DC, USA. 1:1-20.

Burton GW, Ingold KU (1984). ß-carotene: an unusual type of lipid antioxidant. Science 224:569-573.

Ceaser EK, Moellering DR, Shiva A, Ramachandran A, Lander A, Venkartraman A, Crawford J, Patel R, Dickinson DA, Ulasova E, Ji S, Darley-Usmar VM (2004). Mechanisms of signal transduction mediated by oxidized lipids: the role of the electrophile-responsive proteome. Biochem Soc Trans 32:151-155.

Chen $\mathrm{G}$ (2004). Effect of low fat and/or high fruit and vegetable diets on plasma level of 8-isoprostane- $\mathrm{F}_{2}$ alpha in nutrition and breast health study. Nutr Cancer 50:155-160.

Chu F-F, Esworthy RS, Doroshow JH, Doan K, Liu X-F (1992). Expression of plasma glutathione peroxidase in human liver in addition to kidney, heart, lung, and breast in humans and rodents. Blood 79:3233-3238.

Cotelle N (2001). Role of flavonoids in oxidative stress. Curr Topics Med Chem 1:569-590.

Dai J, Mumper R (2010). Plant phenolics: extraction, analysis and their antioxidant and anticancer properties. Molecules 15:7313-7352.

Devasagayam TPA, Tilak JC, Boloor KK, Sane KS, Ghaskadbi SS, Lele RD (2004). Free radicals and antioxidants in human health: current status and future prospects. J Assoc Physicians India 52:794-804.

de Zwart LL, Meerman JH, Commandeur JN, Vermeulen NP (1999). Biomarkers of free radical damage applications in experimental animals and in humans. Free Radic Biol Med 
26:202-226.

El-Beltagi HS (2001). Biochemical studies on some Egyptian plants and its relation with environment. M.Sc. Thesis, Biochemistry Department, Faculty of Agriculture, Cairo University.

El-Beltagi HS (2004). Biochemical studies on cadmium and lead effects on radish plant. Ph. D. Thesis, Biochemistry Department, Faculty of Agriculture, Cairo University Ph.D. Thesis, Biochemistry Department, Faculty of Agriculture, Cairo University.

El-Beltagi HS, Salama ZA, El-Hariri DM (2008). Some biochemical markers for evaluation of flax cultivars under salt stress conditions. J Nat Fiber 5:316-330.

El-Beltagi HS, Mohamed AA, Rashed MM (2010). Response of antioxidative enzymes to cadmium stress in leaves and roots of Radish. Not Sci Biol 2:76-82.

El-Beltagi HS (2011). Effect of roasting treatments on protein fraction profiles, some enzyme activities of Egyptian peanuts. Int J Food Sci Nutr 62:453-456.

El-Beltagi HS, Kesba HH, Abdel-Alim AI, Al-Sayed AA (2011a). Effect of root-knot nematode and two species of crown on antioxidant activity of grape leaves. Afri J Biotechnol 10:12202-12210.

El-Beltagi HS, Ahmed OK, El-Desouky W (2011b). Effect of low doses $\gamma$-irradiation on oxidative stress and secondary metabolites production of rosemary (Rosmarinus officinalis L.) callus culture. Radiat Phys Chem 80:968-976.

Esterbauer H, Schaur JS, Zollner H (1991). Chemistry and biochemistry of 4- hydroxynonenal, malonaldehyde and related aldehydes. Free Radic Biol Med 11:81-128.

Esterbauer H (1996). Estimation of peroxidative damage. A critical review. Pathol Biol 44:25-28.

Ferreri C, Kratzsch S, Landi L, Brede O (2005). Thiyl radicals in biosystems: effects on lipid structures and metabolisms. Cell Mol Life Sci. 62:834-47.

Forman HJ, Fukuto JM, Miller T, Zhang H, Rinna A, Levt S (2008). The chemistry of cell signaling by reactive oxygen and nitrogen species and 4-hydroxynonenal. Arch Biochem Biophys 477:183-195.

Foyer C (1993). Ascorbic acid, 31-58 p. In: Alscher RG, Hess JL (Eds.). Antioxidants in Higher Plants, CRC Press, Boca Raton.

Frankel EN, Neff WE, Bessler TR (1979). Analysis of autoxidized fats by gas chromatography-mass spectrometry: V. Photosensitized oxidation. Lipids 14:961-967.

Fridovich I (1986). Biological effects of the superoxide radical. Arch Biochem Biophys 247:1-11.

Fryer MJ (1992). The antioxidant effects of thylakoid vitamin E ( $\alpha$-tocopherol). Plant Cell Environ 15:381-392.

Gavazza M, Catala A (2006). The effect of $\alpha$-tocopherol on lipid peroxidation of microsomes and mitochondria from rat testis, Prostaglandins. Leuko Ess Fatty Acids 74:247-254.

Grace S, Logan BA (2000). Energy dissipation and radical scav- enging by the plant phenylpropanoid pathway. Philos Trans R Soc London [Biol] 355:1499-1510.

Greenberg ME, Li X-M, Gugiu BG, Gu X, Qin J, Salomon RG, Hazen SL (2008). The lipid Whisker model of the structure of oxidized cell membranes. J Biol Chem 283:2385-2396.

Guajardo MH, Terrasa AM, Catala A (2002). Retinal fatty acid binding protein reduce lipid peroxidation stimulated by long chain fatty acid hydroperoxides on rod outer segments. Biochimica et Biophysica Acta 1581:65-74.

Gutteridge JM, Halliwell B (1990). The measurement and mechanism of lipid peroxidation in biological systems. Trend Biochem Sci 15:129-135.

Gutteridge JM, Halliwell B (1994). Antioxidants in Nutrition, Health, and Disease. Oxford: Oxford University Press.

Gutteridge JM (1995). Lipid peroxidation and antioxidants as biomarkers of tissue damage. Clin Chem 41:1819-1828.

Halliwell B, Chirico S (1993). Lipid peroxidation: its mechanism, measurement, and significance. Amer J Clin Nutr 57:715S-724S.

Halliwell B, Gutteridge JMC (1990). Role of free radicals and catalytic metal ions in human disease: an overview. Methods Enzymol 186:1-85.

Halliwell B, Gutteridge JMC (1999). Free Radicals in Biology and Medicine. $3^{\text {rd }}$ ed. Midsomer Norton, Avon, England: Oxford University Press.

Halliwell B, Murcia MA, Chirico S, Aruoma OI (1995). Free radicals and antioxidants in food and in vivo: what they do and how they work. Crit Rev Food Sci Nutr 35:7-20.

Halliwell B (1994). Free radicals and antioxidants: a personal view. Nutr Rev 52:253-265.

Hertwig B, Steb P, Feierabend J (1992). Light dependence of catalase synthesis and degradation in leaves and the influence of interfering stress conditions, Plant Physiol 100:1547-1553.

Hovenkamp E, Demonty I, Plat J, Lütjohann D, Mensink RP, Trautwein EA (2008). Biological effects of oxidized phytosterols, a review of the current knowledge. Prog Lipid Res 47:37-49.

Ibrahim NM, Eweis EA, El-Beltagi HS, Abdel-Mobdy YE (2012). The effect of lead acetate toxicity on experimental male albino rat. Asian Pac J Trop Biomed 2:41-46.

Ishikawa T, Yoshimura K, Sakai K, Tamoi M, Takeda T, Shigeoka $S$ (1998). Molecular characterization and physiological role of a glyoxysome-bound ascorbate peroxidase from spinach. Plant Cell Physiol 39:23-34.

Kinnula VL, Crapo JD, Raivio KO (1995). Generation and disposal of reactive oxygen metabolites in the lung. Lab Invest 73:3-19.

Kobayashi K, Kumazawa Y, Miwa K, Yamanaka S (1996). $\varepsilon-(\gamma-$ Glutamyl) lysine cross-links of spore coat proteins and transglutaminase activity in Bacillus subtilis. FEMS Microbiol Lett 144:157-160.

Kobeasy MI, El-Beltagi HS, El-Shazly MA, Khattab EAH (2011). Induction of resistance in Arachis hypogaea L. against 
56

Peanut Mottle Virus by nitric oxide and salicylic acid. Physiol Mol Plant Pathol 76:112-118.

Kuhn H (2005). Biologic relevance of lipoxygenase isoforms in atherogenesis. Expert Rev Cardiovasc Ther 3:1099-1110.

Kukic J, Petrovic S, Niketic M (2006). Antioxidant activity of four endemic Stachys taxa. Biol Pharmaceut Bull 29:725729.

Loewus FA (1988). Ascorbic acid and its metabolic products. In: The Biochemistry of Plants, Preiss, J. Academic Press, New York, 14:85-107.

Madhusudhan R, Ishikawa T, Sawa Y, Shigeoka S, Shibata H (2003). Characterization of an ascorbate peroxidase in plastids of tobacco BY-2 cells. Physiol Plant 117:550-557.

Manach C, Scalbert A, Morand C, Remesy C, Jimenez L (2004). Polyphenols: food sources and bioavailability. Amer J Clinical Nutr 79:727-747.

Mann T, Kleilin D (1938). Homocuprein and heptacuprein, copper-protein compounds of blood and liver in mammals. Proc R Soc London B 126:303-315.

Mathis P, Kleo J (1973). The triplet state of B-carotene and of analog polyenes of different length. Photochem Photobiol 18:343-346.

McCord JM, Fridovich I (1969). Superoxide dismutase, an enzymatic function for erythrocuprein. J Biol Chem 244:60496055.

Mishra P, Kumari B, Dubey RS (2013). Differential responses of antioxidative defense system to prolonged salinity stress in salt-tolerant and salt-sensitive indica rice (Oryza sativa L.) seedlings. Protoplasma 250:3-19.

Mittler R, Zilinskas BA (1992). Molecular cloning and characterization of a gene encoding pea cytosolic ascorbate peroxidase. J Biol Chem 267:21802-21807.

Mohamed AA, El-Beltagi HS, Rashed MM (2009). Cadmium stress induced change in some hydrolytic enzymes, free radical formation and ultrastructural disorders in Radish plant. Electron J Environ Agric Food Chem 8:969-983.

Mohamed HI (2011). Molecular and biochemical studies on the effect of gamma rays on lead toxicity in cowpea (Vigna sinensis) plants. Biol Trace Elem Res 144:1205-1218.

Moore K, Roberts LJ (1998). Measurement of lipid peroxidation, Free Radic Res 28:659-671.

Moussa R and Abdel-Aziz SM (2008). Comparative response of drought tolerant and drought sensitive maize genotypes to water stress. Aust J Crop Sci 1:31-36.

Murray RK, Granner DK, Mayes PA, Rodwell VW (2000). Harper's Biochemistry. 25 $5^{\text {th }}$ ed. Stamford, Connecticut: Appleton \& Lange.

Nakano Y, Asada K (1987). Purification of ascorbate peroxidase in spinach chloroplasts; its inactivation in ascorbatedepleted medium and reactivation by monodehydroascorbate radical. Plant Cell Physiol 28:131-140.

Noguchi N, Yamashita H, Hamahara J, Nakamura A, Kuhn $\mathrm{H}$, Niki E (2002). The specificity of lipoxygenase-catalyzed lipid peroxidation and the effects of radial scavenging antioxidants. Biol Chem 383:619-626.

Noguchi N (2008). Role of oxidative stress in adaptive responses in special reference to atherogenesis. J Clin Biochem Nutr 43:131-138.

O'Donnell VB, Freeman BA (2001). Interactions between nitric oxide and lipid oxidation pathways implications for vascular disease. Circ Res 88:12-21.

O’Kane DV, Gill PB, Burdon R (1996). Chilling, oxidative stress and antioxidant response in Arabidopsis thaliana callus. Planta 198:371-377.

Packer L (1991). Protective role of vitamin E in biological systems. Amer J Clin Nutr 53:1050S-1055S.

Parthasarathy S, Santanam N, Ramachandran S, Meilhac O (2000). Potential role of oxidized lipids and lipoproteins in antioxidant defense. Free Radic Res 33:197-215.

Patterson WR, Poulos TL (1995). Crystal structure of recombinant pea cytosolic ascorbate peroxidase. Biochem 34:43314341.

Poli G, Biasi F, Leonarduzzi, G (2008a). 4-Hydroxynonenalprotein adducts: a reliable biomarker of lipid oxidation in liver disease. Mol Aspects Med 29:67-71.

Poli G, Schaur RJ, Siems WG, Leonarduzzi G (2008b). 4-Hydroxynonenal: a membrane lipid oxidation product of medicinal interest. Medic Res Rev 28:569-631.

Price A, Lucas PW, Lea PJ (1990). Age dependent damage and glutathione metabolism in ozone fumigated barley: a leaf section approach. J Exp Bot 41:1309-1317.

Radotic K, Ducic T, Mutavdzic D (2000). Changes in peroxidase activity and isoenzymes in spruce needles after exposure to different concentrations of cadmium. Environ Exp Bot 44:105-113.

Raveh O, Pinchuk I, Fainaru M, Lichtenberg DO (2002). Oxygen availability as a possible limiting factor in LDL oxidation. Free Rad Res 36:1109-1114.

Rennenberg H (1982). Glutathione metabolism and possible biological roles in higher plants. Phytochem 21:2771-2781.

Rice-Evans C, Burdon R (1993). Free radical-lipid interactions and their pathological consequences. Prog Lipid Res 32:71110.

Rice-Evans CA, Miller NJ, Paganga G (1996). Structure antioxidant activity relationships of flavonoids and phenolic acids. Free Radic Biol Med 20:933-956.

Rice-Evans CA, Miller NJ, Paganga G (1997). Antioxidant properties of phenolic compounds. Trends Plant Sci 2:152159.

Roberts LJ, Fessel JP (2004). The biochemistry of the isoprostane, neuroprostane, and isofuran pathways of lipid peroxidation. Chem Phys Lipids 128:173-186.

Roman RJ (2002). P-450 metabolites of acrachidonic acid in the control of cardiovascular function. Physiol Rev 82:131185. 
Scandalias JG (1993). Oxygen stress and superoxide dismutase. Plant Physiol 101:7-12.

Schneider C, Pratt DA, Porter NA, Brash AR (2007). Control of oxygenation in lipoxygenase and cyclooxygenase catalysis. Chem Biol 14:473-488.

Tayefi-Nasrabadi H, Dehghan G, Daeihassani B, Movafegi A, Samadi A (2011). Some biochemical properties of guaiacol peroxidases as modified by salt stress in leaves of salt-tolerant and salt-sensitive safflower (Carthamus tinctorius L.cv.) cultivars. Afri J Biotechnol 10:751-763.

Schroepfer GJ (2000). Oxysterols: modulators of cholesterol metabolism and other processes. Physiol Rev 80:362-554.

Schuller DJ, Ban N, Van Huystee RB, McPherson A, Poulos TL (1996). The crystal structure of peanut peroxidase. Structure 4:311-321.

Seigler DS (1998). Plant Secondary Metabolism. Dordrecht: Kuwar Academic Press.

Sharma P, Dubey RS (2004). Ascorbate peroxidase from rice seedlings: properties of enzyme isoforms, effects of stresses and protective roles of osmolytes. Plant Sci 167:541-550.

Sies H, Murphy ME (1991). Role of tocopherols in the protection of biological systems against oxidative damage. J Photochem Photobiol B 8:211-218.

Slater TF (1984). Free-radical mechanisms in tissue injury. Biochem J 222:1-15.

Sloane DL, Leung R, Craik CS, Sigal E (1991). A primary determinant for lipoxygenase positional specificity. Nature 354:149-152.
Smith LL (1981). Cholesterol Autoxidation, Plenum Press, New York.

Suntres ZE (2011). Liposomal antioxidants for prtotection against oxidant-induced damage. J Toxicol 2011:1-16.

Timmerman KP (1989). Molecular characterization of corn glutathione-S-transferase isozymes involved in herbicide detoxification. Physiol Plant 77:465-471.

Uchida K (2003). 4-Hydroxy-2-nonenal: a product and modulator of oxidative stress. Prog. Lipid Res 42:318-343.

Vangronsveld J, Clijsters H (1994). Toxic effects of metals, in plants and the chemical elements, 150-177 p. In: Farago ME (Ed.). Biochemistry, uptake, tolerance and toxicity, $\mathrm{VCH}$ Publishers, Weinheim, Germany.

Welinder KG (1992). Superfamily of plant, fungal and bacterial peroxidases. Curr Opin Struct Biol 2:388-393.

West JD, Marnett LJ (2006). Endogenous reactive intermediates as modulators of cell signaling and cell death. Chem Res Toxicol 19:173-194.

Yoshimura S, Suemizu H, Taniguchi Y, Arimori K, Kawabe N, Moriuchi T (1994). The human plasma glutathione peroxidase-encoding gene: organization, sequence and localization to chromosome 5q32. Gene 145:293-297.

Zmijewski JW, Landar A, Watanabe A, Dickinson DA, Noguchi N, Darley-Usmar, VM (2005). Cell signaling by oxidized lipids and the role of reactive oxygen species in the endothelium. Biochem Soc Trans 33:1385-1389. 